\title{
XCII. On the periodic times of Saturn's rings
}

\author{
Henry Wilde D.Sc. D.C.L. F.R.S.
}

To cite this article: Henry Wilde D.Sc. D.C.L. F.R.S. (1911) XCII. On the periodic times of Saturn's rings, Philosophical Magazine Series 6, 22:132, 949-950, DOI: 10.1080/14786441208637193

To link to this article: http://dx.doi.org/10.1080/14786441208637193

册 Published online: 20 Apr 2009.

Submit your article to this journal 준

Џll Article views: 2

Q View related articles $₫$ 
X(II. On the Periodic Times of Saturn's Rings. By Henry Wilde, D.Sc., L.C.L., F.R.S.*

T $N$ my paper on the "Origin of Cometary Bodies and Saturn's Rings," read before the Society in October last $\dagger$ a new determination was made of the periodic times of the rings, based on the commonly accepted distance of Mimas, 3.36 Saturnian units. This element of the orbit was derived from observations made by Herschel and subsequently adopted by all astronomical writers.

Recent observations of American astronomers with more powerful telescopes and under more favourable conditions, have reduced the distance of Mimas from the planet to $3 \cdot 16$ units, with the consequent increase in the times of rotation of the rings.

The difference between the older and later determinations is sufficiently large to induce me to place on record for comparison the results computed from both observations and Kepler's third law, as shown and demonstrated in the following tables :-

Distances of Mimas $=3 \cdot 36$ and outer edge of $\operatorname{lin} g \mathrm{~A}=2 \cdot 3$.

(1) $3 \cdot 36^{3}: 2 \cdot 3^{3}:: 22 \mathrm{~h} .37^{2} \mathrm{~m}$. : $x=12 \mathrm{~h} .48^{2} \mathrm{~m}$. for A.

Distances of Mimas $=3 \cdot 36$ and inner edge of ring $\mathrm{C}=1 \cdot 27$.

(2) $3 \cdot 36^{3}: 1 \cdot 27^{3}:: 22 \mathrm{~h} .37^{2} \mathrm{~m} .: x=5 \mathrm{~h} .15^{2} \mathrm{~m}$. for $\mathrm{C}$.

Distances of Mimas $=3 \cdot 16$ and outer edge of ring $A=2 \cdot 3$. (3) $3 \cdot 16^{3}: 2 \cdot 3^{3}:: 22 \mathrm{~h} .37^{2} \mathrm{~m} .: x=14 \mathrm{~h} .4^{2} \mathrm{~m}$. for A.

Distances of Mimas $=3 \cdot 16$ and inner edge of ring $\mathrm{C}=1 \cdot 27$. (4) $3 \cdot 16^{3}: 1 \cdot 27^{3}:: 22 \mathrm{~h} .37^{2} \mathrm{~m} .: x=5 \mathrm{~h} .45^{2} \mathrm{~m}$. for $(\%$

The unit distance, $3 \cdot 16$, for Mimas necessarily involves the correlative reduction of the distances of the other Saturnian satellites, as now set forth in the tables of these elements published by American astronomers.

That Saturn's rings are ejectamenta from the interior of the planet is further evident from the fact that no causal connexion subsists between their times of rotation and that of the planet itself, as the inner edge of the ring ( has a

* Conmunicated by the Author. From the Manchester Memoirs, rol. Iv. 1910-11, no. 14 .

† Manchester Memoirs, vol. lv. 1910-11; Phil. Mag. November 1911. Phil. Mag. S. 6. Vol. 22. No. 132. Dec. 1911. 3 R 
periodic time of only 5 hours 45 minutes, while the axial rotation of Saturn is 10 hours 13 minutes.

The same conclusion may also be drawn with reference to the origin of the two satellites of Mars, as Phobos has a period of only 7 hours 39 minutes, while the axial rotation of the planet is 24 hours 37 minutes.

The comparative minuteness of these bodies, which are estimated to be less than 10 miles in diameter, indicates them as ejectamenta rather than the successive condensations of a nebular substance surrounding the planet.

Saturn's dusky ring and the inner satellite of Mars are the only bodies in the solar system that revolve in a shorter time than their primaries.

\section{Eliments of Saturn's Rings.}

Mimas $=3 \cdot 16$.

\begin{tabular}{|c|c|c|c|c|}
\hline \multirow[b]{2}{*}{ Rings. } & \multicolumn{2}{|c|}{$\begin{array}{c}\text { Distance from centre } \\
\text { of Saturis. }\end{array}$} & \multicolumn{2}{|c|}{$\begin{array}{l}\text { 'Time of } \\
\text { Revolution. }\end{array}$} \\
\hline & Sut. Units. & Miles. & b. & $\mathrm{m}$ \\
\hline Exterior A .............. & 230 & 84,937 & $1+$ & 4 \\
\hline Breadth ................. & $0 \cdot 26$ & $9,60) 2$ & , & $"$ \\
\hline Mid-breadth .......... & $2 \cdot 17$ & 80,138 & 12 & 51 \\
\hline Interior $A \ldots \ldots \ldots \ldots$ & 204 & 75,337 & 11 & 44 \\
\hline Interval ................. & 007 & 2,585 & $"$ & $"$ \\
\hline Exterior $\mathbf{B}$............... & 1.97 & 72,752 & 11 & 8 \\
\hline 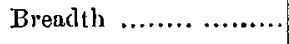 & 047 & 17,357 & $"$ & $"$ \\
\hline Mid-hreadth ............. & 1.735 & 64,073 & 0 & 12 \\
\hline Interior B ................. & $1 \cdot 50$ & $5.5,395$ & 7 & 23 \\
\hline Exterior $\mathrm{C}$............. & $1 \cdot \overline{0} 0$ & 55,395 & 7 & 23 \\
\hline 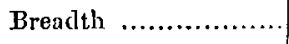 & $0 \cdot 23$ & 8,493 & , & , \\
\hline Mid-breadth ............ & $1 \cdot 385$ & 51,148 & 6 & 33 \\
\hline Interior $\mathrm{C} \quad \ldots \ldots \ldots \ldots \ldots$ & $1 \cdot 2 \bar{T}$ & 46,901 & 5 & 45 \\
\hline Ball Space ............... & 027 & 9,971 & ", & $"$ \\
\hline Sat. Ball ................... & $1 \cdot 00$ & 36,930 & 10 & 13 \\
\hline Mimas ................... & $3 \cdot 16$ & 116,698 & 22 & 37 \\
\hline
\end{tabular}

